\title{
DE DEUTSCHE SCHULE A COLLÉGIO IGUASSÚ: a nacionalização de uma instituição escolar étnica no norte de Santa Catarina
}

\author{
DE LA DEUTSCHE SCHULE AL COLLÉGIO IGUASSÚ: la nacionalización de una \\ escuela étnica em el norte de Santa Catarina
}

\author{
FROM DEUTSCHE SCHULE TO COLLÉGIO IGUASSÚ: the nationalization of an \\ ethnic school in the northern Santa Catarina
}

\author{
Roseli B. Klein ${ }^{1}$ \\ http://orcid.org/0000-0002-3368-5785
}

\begin{abstract}
Resumo
O referido artigo aponta as implicações do processo de nacionalização compulsória a uma escola alemã comunitária coordenada por uma Associação Escolar e mantida por uma Sociedade estabelecida no município de Porto União (SC), criada no final do século XIX e fechada oficialmente em 1939. A pesquisa teve por objetivo mostrar as consequências desse processo de nacionalização da educação, no cotidiano da escola alemã de Porto União (SC), mediante as exigências do Decreto Federal $n^{\circ} 406$, de 04 de maio de 1938, conhecido como Lei da Nacionalização, culminando com o encerramento das atividades da mesma. A investigação utilizou de pesquisa bibliográfica e análise documental tendo como fonte o Livro de Atas da Associação "25 de Julho" de 1938 a 1941. Toma por base os estudos sobre as escolas alemãs em Santa Catarina de Klug (2003) e os estudos sobre as escolas comunitárias no Brasil de Kreutz (2000). Aponta-se como resultado os esforços, por parte dos membros da associação e da comunidade, para manterem a escola em funcionamento e, ao mesmo tempo, a negativa da Secretaria do Interior e da Justiça do Estado de Santa Catarina.
\end{abstract}

Palavras-chave: História da Educação. Escola alemã. Nacionalização do ensino.

\section{Resumen}

Este artículo señala las implicaciones del proceso de nacionalización obligatoria a una escuela comunitaria alemana coordinada por una Asociación Escolar y mantenida por una Sociedad establecida en el municipio de Porto União (SC), creada a finales del siglo XIX y oficialmente cerrado en 1939. La investigación tuvo como objetivo mostrar las consecuencias de este proceso de nacionalización de la educación, en la vida cotidiana de la escuela alemana en Porto União (SC), a través de los requisitos del Decreto Federal No. 406, de 04 de mayo de 1938, conocida como la Ley de Nacionalización, que culmina con el cierre de sus actividades. La investigación utiliza investigación bibliográfica y análisis documental basado en el Libro de Actas de la Asociación "25 de Julho" de 1938 a 1941. Se basa en estudios sobre escuelas alemanas en Santa Catarina de Klug

\footnotetext{
${ }^{1}$ Doutora em Educação. Professora adjunta do Curso de Pedagogia da Universidade Estadual do Paraná (UNESPAR), campus de União da Vitória (Brasil). Membro do Grupo de Estudos e Pesquisas em Práxis Educativa -(GEPPRAX). E-mail: roseli.klein@hotmail.
}

\section{Como referenciar este artigo:}

KLEIN, R. B. De Deutsche Schule a Collégio Iguassú: a nacionalização de uma instituição escolar étnica no norte de Santa Catarina. Revista Pedagógica, v. 23, p. 1-26, 2021. 
(2003) y estudios sobre escuelas comunitarias en Brasil por Kreutz (2000). Los resultados señalan los esfuerzos, por parte de los miembros de la asociación y la comunidad, por mantener la escuela en funcionamiento y, al mismo tiempo, la negativa de la Secretaría de Gobernación y Justicia del Estado de Santa Catarina.

Palabras clave: Historia de la Educación. Colegio Aleman. Nacionalización de la educación.

\begin{abstract}
This article points out the implications of the process of compulsory nationalization to a German community school coordinated by a School Association and maintained by a Society established in the municipality of Porto União (SC), created at the end of the 19th century and officially closed in 1939. The research aimed to show the consequences of this process of nationalization of education, in the daily life of the German school in Porto União (SC), through the requirements of Federal Decree No. 406, of 04 of May 1938, known as the Nationalization Law, culminating in with the closure of its activities. The investigation used bibliographic research and documentary analysis based on the Book of Minutes of the Association " 25 de Julho" from 1938 to 1941. It is based on studies on German schools in Santa Catarina de Klug (2003) and studies on community schools in Brazil by Kreutz (2000). The result point out the efforts, on the part of the members of the association and the community, to keep the school functioning and, at the same time, the refusal of the Secretariat of Interior and Justice of the State of Santa Catarina.
\end{abstract}

Keywords: History of Education. German school. Nationalization of education.

\title{
INTRODUÇÃO
}

Com a imigração europeia no sul do Brasil, difundiram-se as escolas isoladas e étnicas em áreas rurais e urbanas. Nas colônias surgiram as escolinhas isoladas e multisseriadas cuja instrução ficava sob a coordenação de um professor normalmente escolhido pela comunidade, que se tratava de uma pessoa com um nível mais elevado de escolarização. Nessas localidades instalaram-se escolas confessionais étnicas católicas organizadas por congregações religiosas tanto femininas como masculinas, algumas em regime de internato, e outras também da confissão evangélica luterana, principalmente em áreas de colonização alemã.

A instituição em estudo refere-se a uma escola comunitária em área urbana, município de Porto União (SC), no planalto norte catarinense, coordenada por uma Associação Escolar, e mantida por uma Sociedade originária da comunidade alemã: a Comunidade Evangélica de Confissão Luterana do Brasil. A escola mantinha um pequeno internato e oferecia ensino até a sétima série (ALTMANN, 1991), iniciou suas atividades em 
1887 (IHLENFELD, 2011) e encerrou oficialmente em 15 de março de 1939 (COLLÉGIO IGUASSÚ, 1938-1941, p. 9 verso).

Justifica-se a investigação tendo por base o Livro de Atas da Associação 25 de Julho com registros compreendidos entre os anos de 1938 a 1941, nos quais constam as tratativas com o professor Luiz Sanches Bezerra da Trindade, Inspetor das Escolas Particulares e Nacionalização do Ensino em Santa Catarina² e a Secretaria do Interior e da Justiça de Florianópolis, tendo por finalidade as adequações de uma escola alemã aos padrões de uma escola nacionalizada proposta pelo Governo Vargas no Brasil.

A pesquisa teve por objetivo mostrar as consequências do processo de nacionalização da educação no cotidiano da escola alemã de Porto União (SC) mediante as exigências do Decreto Federal $n^{\circ}$ 406, de 04 de maio de 1938, conhecido como Lei da Nacionalização, culminando com o encerramento das atividades da mesma. A investigação utilizou de pesquisa bibliográfica e análise documental.

O artigo apresenta, no primeiro momento, o histórico da escola contextualizado com a realidade na qual esteve inserida amparado em pesquisa anterior, desenvolvida com base em atas de 1919 a 1938 (IHLENFELD, 2011) e na autobiografia de um professor que atuou na escola alemã entre os anos de 1934 a 1939 (ALTMANN, 1991). No segundo momento apresenta fragmentos das atas de 1938 a 1941 (COLLÉGIO IGUASSÚ, 1938-1941) vinculados a história da educação brasileira e ao processo de nacionalização imposto às escolas dos imigrantes 3 .

\section{UMA DEUTSCHE SCHULE PARA CATÓLICOS E LUTERANOS}

A escola alemã localizava-se no município de Porto União (SC) ao norte do estado de Santa Catarina. O local de sua construção constitui-se de um dos pontos mais altos da cidade que situa-se em meio ao Vale do Iguaçu ladeado pelo rio de mesmo nome (Rio

\footnotetext{
${ }^{2} O$ professor Luiz Sanches Bezerra da Trindade passou a comandar a Inspetoria Geral de Escolas particulares e nacionalização do Ensino, pelo Decreto n. 124, de 18 de junho de 1938. (COLEÇÃO DE DECRETOS-LEIS de 1938 apud UNGLAB, 2015).

${ }^{3}$ A divulgação das informações do referido documento foi autorizada pela pessoa que detém a posse do mesmo, com a garantia de anonimato.
} 
Iguaçu $)^{4}$. O município em questão e toda a região foi povoado por diferentes grupos de imigrantes europeus ${ }^{5}$. Segundo Silva (2006, p. 45) os primeiros colonos estrangeiros chegaram à cidade, numa lancha, em junho de 1881, consistiam em cerca de "24 pessoas, na maioria alemães".

Essa população imigrante, em sua maioria, foi se estabelecendo em áreas rurais e também em regiões urbanas e organizavam, inicialmente, a Igreja e a escola, que funcionavam como centro social e cultural mantenedores da cultura de origem. Klug (2003, p. 142) destaca que "falar de escola alemã em Santa Catarina implica a necessidade de se levar em conta outra instituição extremamente importante na história da imigração, ou seja, a igreja. Em torno dessas duas instituições, se organizou a vida, o cotidiano das colônias".

Com o Collégio Iguassú, a antiga escola alemã, não foi diferente, pois sua criação ocorreu em função de existir um número significativo de imigrantes alemães na cidade de Porto União (SC), entre eles alguns pertencentes a religião Luterana, e segundo Ihlenfeld (2011):

\begin{abstract}
A igreja Evangélica Luterana do Brasil propiciou a criação de uma escola comunitária que pertencia a uma sociedade escolar [...], fundada em 1887 [...]. Inicialmente o colégio funcionava em uma casa de madeira em terreno de propriedade da Comunidade Evangélica de Confissão Luterana de Porto União da Vitória. (IHLENFELD, 2011, p. 35).
\end{abstract}

As escolas comunitárias, organizadas por Igrejas Evangélicas Luteranas com a maioria de seus membros constituídos por alemães ou descendentes, surgiram no Rio Grande do Sul, cuja organização tomou por base o Sínodo de Missouri, nos Estados Unidos em 1847. Este teve como meta o realinhamento das ações pastorais da Igreja Luterana com as proposições de Lutero, tanto no aspecto das bases doutrinárias, quanto na criação de

\footnotetext{
${ }^{4} \mathrm{O}$ Rio Iguaçu nasce próximo à capital do estado do Paraná (Curitiba) e atravessa todo o estado desaguando na fronteira com o Paraguai e Argentina. A região em estudo denomina-se Vale do Iguaçu, por possuir essa característica e contempla as cidades de União da Vitória (sul do Paraná) e Porto União (norte de Santa Catarina), separadas geograficamente pelos trilhos do trem da antiga estrada de ferro que ligava São Paulo ao Rio Grande do Sul.

${ }^{5}$ A região de abrangência de Porto União (SC) contempla cerca de 300.000 habitantes, estendendo-se por 12 municípios do estado do Paraná e 8 municípios do estado de Santa Catarina (IBGE, 2010). Colonizaram essa região os imigrantes poloneses, ucranianos, alemães, italianos, seguidos de grupos menores: franceses, austríacos, ingleses, russos, sírio-libaneses, suíços, holandeses, portugueses, espanhóis, etc. (WACHOWICZ, 2001 e KLUG, 2003).
} 
escolas que incluíam as respectivas doutrinas. Pastores inspirados por esse Sínodo chegaram ao Rio Grande do Sul e empenharam-se em disciplinar as linhas doutrinárias e a escola de acordo com as normativas deste. O trabalho iniciado gerou os sínodos riograndenses que passaram a regulamentar as ações dos pastores e professores formados de acordo com a confissão luterana (WEIDUSCHADT; TAMBARA, 2012).

Foram criados os seminários teológicos e pedagógicos que preparavam pastores e professores, e muitos pastores "formavam-se alcançando ambas as titulações, vindo a atuar na dupla função em escolas paroquiais e nas comunidades” (WEIDUSCHADT, 2012, p. 54). A Igreja Evangélica Luterana apoiou as escolas comunitárias de caráter confessional, tendo em vista a influência do Movimento da Restauração ${ }^{6}$, e pelo fato dos Concílios Gerais do Sínodo Rio-Grandense tratarem do tema escola (KREUTZ, 2000). Outro fator importante que contribuiu para a organização das escolas comunitárias, deve-se ao fato de ainda no início do século XX, o Brasil não dispor de um ensino público que atendesse toda a população brasileira em idade escolar.

Segundo Kreutz (2000) as escolas comunitárias não se desenvolveram de forma isolada, cada uma restrita a seu núcleo rural e/ou urbano. Pois, ao serem criadas, vinculavam-se a uma instância maior, submetidas a uma coordenação que direcionava o processo escolar. Recebiam todo um conjunto de estruturas de apoio (formação do professor, material didático, frequência obrigatória, etc.)

Em Porto União uma segunda escola foi edificada, desta vez construída em alvenaria, na década de 1930 com o apoio da comunidade local, pois o número de alunos crescia e a cidade prosperava. O professor Friedhold Altmann, docente na escola entre os anos de 1934 a 1939, registra as primeiras impressões quando chegou ao município no ano de 1934 (ALTMANN, 1991):

Porto União e União da Vitória, em verdade formam uma única cidade, uma vez que são separadas apenas por uma linha férrea, a São Paulo - Rio Grande. Essa cidade tinha um mesclado colorido quanto à procedência da população. Havia uma significativa participação de teuto -brasileiros vindos do Rio Grande do Sul,

\footnotetext{
${ }^{6}$ Esse movimento refere-se à restauração da Fé ameaçada pela sociedade que gradativamente implantava a laicização das instituições, e principalmente da instituição escolar. Lutero adverte os pais dizendo que, se eles não cumprissem sua obrigação de encaminhar os filhos à escola, se tornariam os responsáveis caso o serviço de Deus se arruinasse; e também os relembra de que não são os donos absolutos de seus filhos, pois estes também pertencem a Deus e por isso devem entregá-los para Ele, enviando-os à escola de forma a garantir sua instrução que muito poderia contribuir para a obra cristã. (BARBOSA, 2007, p. 179).
} 
à procura de novas terras, e também muitos alemães vindos da Alemanha nos anos de 1923/1924, quando a situação econômica de lá tornara-se insuportável. Sofriam-se as consequências das reparações de guerra, assim como da subsequente inflação e falta de trabalho. Aqui eles tinham iniciado uma nova existência. Eram artificies das mais variadas profissões. Havia pedreiros, marceneiros, funileiros, alfaiates, pintores, músicos, artistas de teatro, mecânicos, construtores, etc. Realmente tinha de tudo. Ao lado deles havia boa proporção de sírios e libaneses, que o povo chamava simplesmente de turcos. Estes dominavam grande parte do comércio. Também havia descendentes de italianos, vindos do Rio Grande. Havia muito poucos negros. Em toda a cidade respirava-se um ar "novo". Muitas casas eram de madeira. Nas ruas faltava calçamento e entre a população havia muita gente jovem. Tudo estava em crescimento e desenvolvimento. Trabalhava-se muito. Como as duas cidades pertenciam a estados diferentes, havia guaritas aduaneiras, nas ruas de ligação. Quiséssemos comprar um balde na Funilaria Woeltje, ao passar de um estado para o outro tínhamos que pagar uma taxa. A população em geral, principalmente os alemães e libaneses, tinham um alto nível cultural. Não se sentia diferenças de classe. Em Porto União havia dois clubes: o Untersützungsveren (Sociedade Beneficente), era tipicamente operário, mas aceitava todos como sócios. Ele cobrava uma certa mensalidade em dinheiro com que auxiliava sócios necessitados e doentes; o outro era mais recreativo e esportivo. Lá também funcionava a orquestra Elite [...]. (ALTMANN, 1991, p. 69).

A realidade local descrita sob o olhar de um jovem professor deixa transparecer o idealismo profissional e aponta para a necessidade de uma escola que fosse continuadora desse suposto progresso e evolução cultural da sociedade. O novo prédio, construído na década de $1930^{7}$, resultou de um trabalho comunitário motivado pela comunidade luterana, pois estes valorizavam o processo escolar. Segundo Kreutz (2000):

Em todos os relatórios dos Concílios Gerais do Sínodo Rio-Grandense, o tema escola aparece com ênfase. E a evolução das comunidades protestantes luteranas demonstra o quanto a Igreja assumiu a coordenação no processo de difusão das escolas comunitárias. Entre os imigrantes alemães, o número de escolas comunitárias luteranas foi superior ao das católicas. (KREUTZ, 2000, p. 3-4).

\section{E em decorrência da importância dessa instituição escolar a comunidade se} empenhou para construir esse novo prédio. Altmann (1991) comenta a esse respeito:

[...] havia muita coragem e espírito de colaboração. Um alemão, construtor formado, ofereceu logo os seus serviços, fez a planta deu orientação, fiscalizou a construção, tudo sem cobrar nada. O frete de todo o material de construção foi presente de um grupo de carroceiros. Os marceneiros e os carpinteiros também

\footnotetext{
${ }^{7}$ A data provável de construção ocorreu depois do ano de 1934. O professor Friedhold chegou a Porto União em 1934 e relembra um fato durante sua subida ao Morro da Cruz (local turístico da cidade): "[...] fiz um passeio ao Morro da Cruz, juntamente com o pastor. Lá, sentados na grama, contemplávamos o belo panorama. No meio da cidade, à luz do pôr-do-sol, se via a nossa escola em construção" (ALTMANN, 1991, p. 71).
} 
trabalharam de graça. Os pedreiros colaboraram cobrando preço reduzido pela mão-de-obra. Os professores passaram a ensaiar e apresentar noitadas artísticas, cuja renda era designada à obra. Os grupos de teatro da cidade também programaram espetáculos em prol da construção. A orquestra fez concertos beneficentes. Também houve festa escolar, tipo quermesse. Os alunos e a juventude levantavam tijolos. As senhoras faziam chás em benefício das obras. Eu vi com entusiasmo o que uma comunidade pode, quando realmente quer, reúne as forças e puxa parelho. Era uma alegria trabalhar num ambiente assim [...]. $O$ nosso diretor tinha boas relações com o cônsul alemão de Joinville. Ao explicarIhe o nosso trabalho e o nosso projeto, também recebeu de lá verba em dinheiro. Nem demorou tanto quanto tínhamos calculado, e o novo prédio estava pronto. Por intermédio do cônsul ainda recebemos valioso material didático: livros de leitura para a biblioteca, obras de consulta, coleção de mapas geográficos e quadros murais, modelos anatômicos e outros. (ALTMANN, 1991, p. 70).

A nova escola (figura 1) apresentava uma boa estrutura de recursos didáticos, possuía um internato para atender as crianças de comunidades rurais "atendia as localidades vizinhas, colonizações novas, no interior, como Cruz Machado(PR), Nova Santa Cruz (Porto União - SC), Maratá (Porto União - SC) e outras, vinham interessados que procuravam escolas para seus filhos" (ALTMANN, 1991, p. 69).

Figura 1 - Escola alemã [1938?], mais tarde Collégio Iguassú.

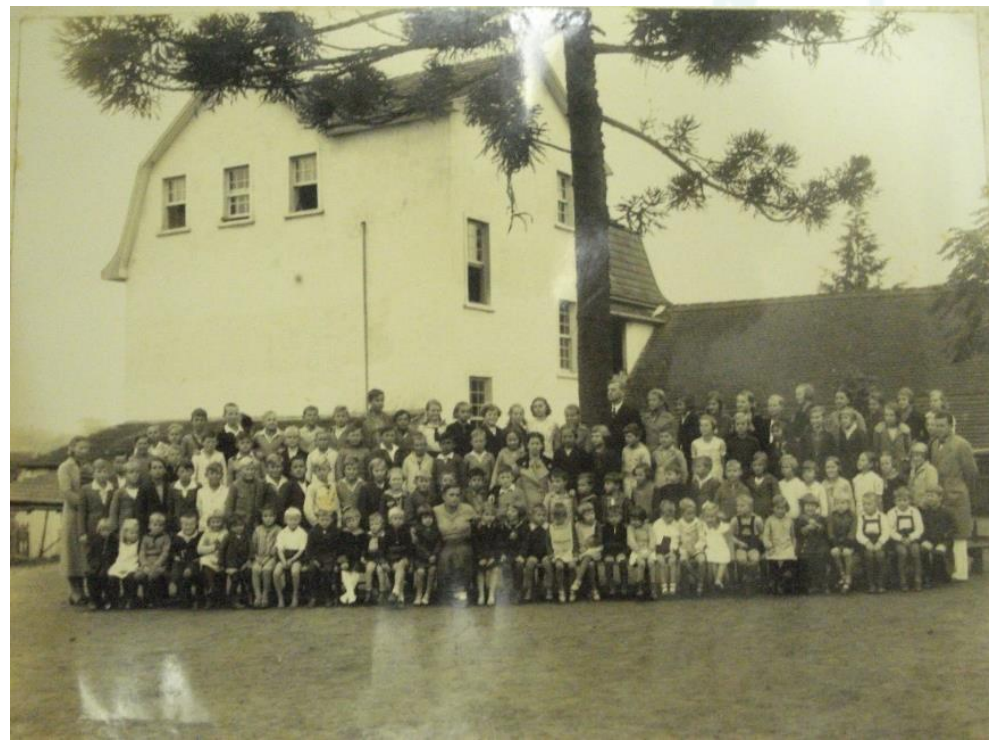

Fonte - Acervo Particular de Willy Carlos Jung ${ }^{8}$

Inicialmente a escola alemã atendia alunos luteranos e católicos, entretanto, mesmo antes da conclusão do novo prédio, alguns alemães católicos passaram a

\footnotetext{
${ }^{8}$ Essa imagem de data provável [1938?] foi fotografada por Carlos Egon Ihlenfeld (IHLENFELD, 2011). Alunos e professores da escola, e também membros da sociedade local, guardaram e ainda guardam uma cópia dessa foto em seus acervos particulares, como foi o caso do Sr. Willy Carlos Jung (in memoriam).
} 
frequentar uma outra escola criada pelos frades franciscanos alemães que atendiam a Igreja católica local (Igreja Matriz da cidade). Os frades fundaram a Escola Paroquial São José9 no ano de 1932. Segundo Melo Junior (1993):

\begin{abstract}
Os imigrantes alemães, na maioria protestantes, criaram juntamente com os católicos de Porto União a chamada Escola Alemã [...]. Com o passar do tempo essa escola ficou predominantemente nas mãos dos protestantes. No ano de 1931, os Padres Franciscanos mudaram-se para o novo convento, a atual casa paroquial (ao lado da Igreja Nossa Senhora das Vitórias em Porto União), abrindo dessa maneira, espaço para a criação de uma escola. No ano seguinte foi fundada por Frei Clemente e Frei Guilherme, a Escola Paroquial São José, que serviria também de internato. Começou a funcionar nas dependências da antiga Casa Paroquial [atualmente dependências da APAE de Porto União]. (MELO JUNIOR, 1993, p. 5).
\end{abstract}

Percebe-se mais uma vez a estruturação da escola sob a organização da Igreja, seja ela protestante ou católica. No Livro Tombo da Igreja católica encontra-se o registro: "no dia 15 de fevereiro [1932] foi aberta uma nova Escola Parochial na antiga casa dos Padres Franciscanos" (PARÓQUIA PORTO UNIÃO, 1909-1941, p. 59).

Mesmo com a criação da escola católica, ainda havia estudantes e professores católicos na escola alemã segundo relata Altmann (1991):

Nosso corpo docente era jovem e alegre. Todos eram solteiros e moravam na escola que também mantinha um pequeno internato. O programa ia até a sétima série e era organizado por nós mesmos. Dois professores eram formados pelo seminário católico para formação de professores, de Novo Hamburgo. Eu e meu colega, o diretor, vínhamos do seminário evangélico de São Leopoldo. A professora do jardim tinha feito curso superior de Educação Física em Berlim, onde também se formara professora jardineira. (ALTMANN, 1991, p. 69).

O novo prédio construído atraiu muitos estudantes, "os pequenos internatos estavam lotados. A nossa fama se tinha divulgado. O nosso conceito era dos melhores" (ALTMANN, 1991, p. 76). Quanto as práticas pedagógicas, o colégio oferecia o ensino da língua alemã no currículo, o canto coral, realizava apresentações teatrais, danças populares e rítmicas das crianças do jardim de infância, havia os desfiles no Dia do Colono, o qual era festejado por toda a cidade. Junto à escola existia um grupo de juventude, formado por ex-

9 O Colégio São José, antiga Escola Paroquial, pertencia aos freis da Primeira Ordem dos Franciscanos Menores da província de São Paulo, Imaculada Conceição de Maria, que passou, a partir de 1935, à Congregação dos Irmãos dos Pobres de São Francisco pela doação do bispo de Lajes, Dom Daniel Hostin, e funciona até a atualidade. Essa instituição católica teve como professores os freis alemães, foi criada em 1932 [...]. O Colégio nasceu após a divisão da escola alemã existente em Porto União. A separação se deu devido as divergências religiosas internas entre os professores protestantes e católicos [...]. (GOHL, 2017, p. 78-79). 
alunos e também membros da comunidade que se reuniam duas vezes por semana para encontros que faziam surgir espaços para leituras, canto, teatro e dança do folclore alemão e brasileiro, e segundo Altmann (1991):

Um professor, vindo da Alemanha, tinha muita experiência em atividades como essa. A professora de educação física ensaiava bailados. Apresentávamos horas de arte. Nos domingos fazíamos excursões. Íamos nos banhar no Iguaçu. Fundamos uma sociedade de ginástica, que se dedicava principalmente à prática de atletismo. (ALTMANN, 1991, p. 70).

Os alunos evangélicos recebiam o ensino religioso porque os frades, já atendendo a Escola Paroquial, não se deslocavam mais até a escola alemã para ensinar religião (ALTMANN, 1991). Essas práticas pedagógicas estavam inseridas no cotidiano da escola.

Quanto aos professores, esses eram contratados pela associação. Por ocasião da professora do jardim de infância ter se casado, a escola teve que contratar uma outra docente. O diretor dirigiu-se até a cidade de Blumenau onde existia um seminário para formação de professoras jardineiras ${ }^{10}$, e assim também ocorreu quando a associação teve que dispensar professores alemães e contratar professores brasileiros natos para atender as exigências do processo de nacionalização do ensino.

Quanto a nomenclatura da escola, encontram-se em boletins escolares: Deutsche Schule até o ano de 1933, Colégio Teuto-Brasileiro de 1934 a 1938. Na sequência utilizou-se a nomenclatura Colégio Iguassu a partir de 3 de agosto de 1938. O fechamento definitivo ocorreu em 15 de março de 1939. (COLLÉGIO IGUASSÚ, 1938-1941, p. 9 verso).

No ano de 1938 a secretaria do Interior e da Justiça de Florianópolis, na pessoa do Inspetor Geral das Escolas Particulares e Nacionalização do Ensino, Luiz Sanches Bezerra da Trindade, solicitou algumas adequações da escola para que a mesma continuasse em funcionamento obedecendo ao Decreto Federal $n^{\circ}$ 406, de 04 de maio de 1938, conhecido como Lei da Nacionalização. O parecer dessa secretaria, em 15 de março de 1939, optou

\footnotetext{
${ }^{10}$ Foi recomendada a professora Ricarda Saettler, filha de um ex-diretor do colégio alemão (Deutsche Schule) de Blumenau. Lá existia uma escola para o lar, para moças. Nessa mesma escola também funcionava um seminário para formação de professoras jardineiras [...]. Poucos dias antes do início letivo de 1936, ela anunciou sua vinda [...]. Era alemã, vinda da Alemanha [...]. (ALTMANN, 1991, p. 76-77). Em 1936, Ricarda Saettler tornou-se esposa do professor Friedhold Altmann, a festa do casamento aconteceu nas dependências da escola. (ALTMANN, 1991).
} 
Revista do Programa de Pós-Graduação em Educação da Unochapecó ISSN 1984-1566 (on-line) ISSN 1415-8175 (impressa)

pelo "fechamento definitivo da Escola” por ela apresentar-se uma ameaça a nacionalização (COLLÉGIO IGUASSÚ, 1939, p. 9 verso).

\section{A NACIONALIZAÇÃO DO ENSINO: TRADIÇÃO, COSTUMES E LÍNGUA CEIFADOS PELO ABRASILEIRAMENTO IMPOSITIVO}

O Regime Republicano brasileiro almejava uma educação laica que formasse um cidadão alfabetizado e consciente de seus deveres cívicos, a própria Constituição priorizava um ensino oficial, público e laico, e indicava alguns rumos para a efetivação desse propósito. Era necessário que o Brasil se transformasse em uma nação à altura de outras civilizações do século. O meio utilizado foi a escola primária que atingiria uma parcela maior da população. Houve a implantação dos Grupos Escolares, propagou-se o entusiasmo pela educação, surgiram reformas educacionais e estabeleceu-se a intenção de padronizar uma língua e cultura nacional. O Estado de Santa Catarina também queria alcançar este status cultural previsto pelo regime republicano. Através de várias reformas educacionais passou a organizar o ensino catarinense, tendo como pano de fundo a nacionalização, devido ao grande número de imigrantes que compunha a população do Estado. Segundo Fiori (1991) a nacionalização do ensino no Estado de Santa Catarina aconteceu em dois momentos: a primeira de 1911 a 1935, com a Reforma Orestes Guimarães, proporcionando o ensino público às áreas de colonização estrangeira no Estado, e a segunda de 1935 a 1945, marcada pelas reforma efetuadas pelos professores Luiz Sanches Bezerra da Trindade, João dos Santos Areão e Elpídio Barbosa, e no ano de 1937 com a implantação do Estado Novo, exigiu-se a nacionalização do ensino de forma mais autoritária, levando ao fechamento de várias escolas que não ministravam o ensino em português (FIORI, 1991).

Essas ações no setor da educação, mais especificamente a partir da década de 1930, foram em parte reflexos de uma política nacional e internacional. Na Alemanha, o governo oferecia insegurança para o povo alemão e estendia os efeitos para os alemães fixados em terras brasileiras. No Brasil, o governo Vargas assumia algumas posturas similares e sentiase uma onda de autoritarismo que também se manifestava em todo o mundo (ALTMANN, 1991). No ano de 1938 foi publicado o Decreto Federal $n^{\circ}$ 406, de 04 de maio, conhecido como Lei da Nacionalização que determinava em seus Artigos de 85 a 87 que em todas as 
escolas rurais do país, o ensino de qualquer matéria deveria ser ministrado em português; as escolas deveriam ser regidas por brasileiros natos, não poderia se ensinar o idioma estrangeiro; os livros destinados ao ensino primário seriam exclusivamente escritos em língua portuguesa, entre outras medidas nacionalizadoras. (BRASIL, 2021). Tolher o ensino da língua alemã nas escolas, ou fechar essas escolas seria um meio de submeter os alemães ao jugo das autoridades brasileiras e ao mesmo tempo padronizar o ensino em língua nacional mesmo que obrigatoriamente. Havia uma resistência dos imigrantes alemães em aceitar um ensino laico e desligado dos princípios religiosos, pois segundo Kreutz (2000):

\begin{abstract}
A tensão entre Estado laico, inspirado nas perspectivas da llustração, e as Igrejas cristãs, sob o Romantismo Conservador, foi muito forte nos países de origem dos imigrantes europeus que não aceitaram pacificamente a expansão do ideário da Revolução sob o signo do Liberalismo. Consideravam-no uma ameaça para a tradicional ordem política e religiosa. Por isso nestes países ensaiou-se uma resistência ao avanço do ideário liberal, conjugando-se esforços num movimento em favor da restauração da antiga ordem política e social, inspirando-se no Romantismo, na sua corrente conservadora. (KREUTZ, 2000, p. 163).
\end{abstract}

Essa situação ocorria também em terras brasileiras, pois as igrejas cristãs reagiam contrariamente ao avanço do liberalismo ateu e organizavam suas escolas comunitárias de caráter confessional e toda a estrutura de apoio (KREUTZ, 2000).

As escolas imigrantes tentaram ao longo dos anos driblar as normativas de nacionalização do ensino cumprindo em parte as determinações legais, ou até mesmo cumpriram as normativas e mantiveram uma espécie de ensino paralelo, onde a língua estrangeira era ensinada em turnos diferenciados, aos sábados, ou muitas vezes adotavam um ensino bilíngue longe da presença de inspetores escolares. Entretanto, outros decretos surgiram e reprimiram cada vez mais a luta pela manutenção dessa modalidade de escola, segundo Renk (2008):

A política de nacionalização era severa e possibilitava a aplicação de multas aos estabelecimentos que a descumprisse. Alguns professores se aposentaram, outros se naturalizaram e também houve a demissão de professores estrangeiros. As escolas de imigrantes fecharam definitivamente as portas, mas as escolas religiosas perderam o caráter étnico e algumas poucas como escolas públicas" (RENK, 2008, p. 4294).

As proposições da nacionalização do ensino, no ano de 1938, alteraram as condições de funcionamento da escola alemã de Porto União (SC). De posse das atas (17 atas) da 
Associação 25 de Julho (21 de junho de 1938 a 28 de janeiro de 1941) a qual organizava a vida dessa instituição, verificam-se algumas ações. Na abertura do Livro consta a seguinte inscrição: Livro de Atas da Associação 25 de Julho Nacionalizada. Com a palavra <nacionalizada> já se subentende que havia um esforço da associação para adaptar algumas normativas a fim de ajustá-las a um modelo de escola nacionalizada proposto a nível nacional. Altmann (1991) relata alguns fatos:

Veio a comunicação da chegada de uma comissão de nacionalização a Porto União, especificamente para nacionalizar clubes e principalmente o Colégio Teuto-Brasileiro. Na noite marcada, a comissão veio, composta de alguns militares e outros civis. A reunião, em conjunto com a nossa diretoria, aconteceu na escola. Foram examinados os estatutos, ainda escritos em língua alemã. Foram vistos os programas, as atas, livros escolares, material didático, nacionalidade dos professores [...]. Alguns membros da diretoria eram alemães natos. Tinham de ser substituídos por brasileiros [...]. O diretor, um professor e a professora jardineira não tinham nascido no Brasil, e deviam ser afastados da escola. Nossas objeções por tratarem-se de pessoas que desde sua infância tinham vivido no Brasil, onde também tinham estudado, não foram aceitas. A lei se referia ao lugar de nascimento. As atas tinham que ser escritas em português [...]. Os estatutos tinham que ser modificados e redigidos em português [...]. Do programa escolar tinha de ser afastado o estudo da língua alemã. Verificaram que na biblioteca havia muitos livros em alemão. Tinham de ser suprimidos. Verificaram o material de ensino e lá encontraram uma bonita coleção de mapas geográficos e quadros murais. Os mapas tinham sido doados pela Alemanha, através do consulado. Sua legenda era em alemão. Em vez de estar escrito Mapa da África, lá constava Karte von Africa. Era o suficiente. Tudo isso tinha de ser eliminado. Também avisaram que era rigorosamente proibido falar em língua alemã, tanto por parte dos professores como dos alunos, na aula e também nos recreios. Foi dado um prazo de algumas semanas para que tudo fosse cumprido [...]. O diretor, a professora jardineira e um professor tinham de ser afastados da escola. Isso não era tão fácil. Mas conseguimos. O nosso diretor logo achou colocação em Niterói, Rio de Janeiro. Eu fui indicado como seu substituto. O professor achou emprego numa firma em Curitiba. A professora ficou sem trabalho. Tínhamos que achar uma substituta. Encontramos uma professora brasileira [...]. Em lugar do professor também se achou outro. A mudança exigida tinha efeitos sensíveis e grandemente negativa sobre o nível de ensino da escola [...]. A exclusão total da língua alemã dificultava o trabalho, pois havia crianças que vinham à escola ou ao jardim, sem saber falar o português [...]. (ALTMANN, 1991, p. 79).

No dia 21 de junho de 1938 realizou-se a eleição de uma nova diretoria "nos moldes da Lei de Nacionalização, reunidos na sede da Associação 25 de Julho" (COLLÉGIO IGUASSÚ, 1938-1941, p. 1). Foram eleitos o presidente e seu vice, o secretário, o segundo secretário, tesoureiro, orador, e seis conselheiros. O cargo de Diretor da escola ficou sob a responsabilidade do professor Friedhold Altmann. Em 29 de junho de 1938 esta diretoria 
prestou contas dos recursos financeiros disponíveis, e houve a solicitação de aumento salarial pelo diretor da escola, o que lhe foi concedido (COLLÉGIO IGUASSÚ, 1938-1941):

Tendo sido pedido augmento de vencimento pelo Snr. Diretor, foi deliberado pela directoria o aumento de Rs: 75.000 sobre os Rs: 400,00 que recebia até agora, a contar do mez de Julho a Setembro do corrente anno, inclusive. Após decorrido esse prazo, a Directoria submetterá a estudo o estado financeiro da Associação para conceder ou não, mais aumento pedido pelo Snr. Director. (COLLÉGIO IGUASSÚ, 1938-1941, p. 2).

Também nesta data, verificando a necessidade de uma professora para o jardim de infância, a diretoria autorizou o presidente da associação a contratar essa docente.

Nestas duas situações percebe-se a dinâmica de uma escola comunitária mantida por uma sociedade, cuja associação escolar tinha a função de gerenciar as demandas da instituição. Ainda nessa reunião foram aceitos onze novos sócios na maioria alemães. Segundo Renk (2009):

As escolas comunitárias ou sociedades-escola eram construídas por meio de iniciativas comunitárias, funcionando em espaços próprios. A partir da cobrança de mensalidades, as sociedades pagavam o professor, mantinham as escolas, compravam o mobiliário e o material escolar. Quando não havia controle estatal, não seguiam os currículos e nem a organização das escolas públicas [...]. O ensino era na língua de origem do grupo e eram escolas laicas. (RENK, 2009, p. 19).

Em 3 de agosto de 1938 o presidente da Associação leu o despacho emitido pela Secretaria do Interior e Justiça de Florianópolis sobre o registro da Associação 25 de Julho e licença para o funcionamento da escola (COLLÉGIO IGUASSÚ, 1938-1941):

Friedhold Altmann requer licença para o funcionamento do Collégio mantido pela Associação 25 de Julho de Porto União. Apresenta, entretanto como responsável pelo estabelecimento o snr. [?]. Residente em União da Vitória, Estado do Paraná. Não pode ser aceito por inconveniente aos interesses do ensino. Deve, assim, o requerente apresentar o nome de pessoa residente na sede da escola, como responsável por ella, nos termos do Decreto Lei $n^{\circ} 88,31-3-38$, bem como mudar o nome do estabelecimento de acordo com o parecer do Departamento de Educação, baseado no artigo 10 Parágrafo único daquele Decreto-Lei. É concedido o prazo de 15 dias para o cumprimento dessas determinações. Intime-se. (COLLÉGIO IGUASSÚ, 1938-1941, p. 2, verso).

A Secretaria do Interior e da Justiça posiciona-se contrária ao nome indicado como presidente da Associação, por este não residir na cidade de Porto União (SC) e, ao que tudo indica por ser uma pessoa de nacionalidade alemã. Este é apenas um dos muitos 
empecilhos que irão culminar com o fechamento da escola. A Associação elegeu o secretário para ocupar o cargo de presidente e incumbiu o novo presidente a contratar uma professora para as aulas de educação física para a seção feminina. O registro na ata (3 de agosto de 1938), sugere o nome de Associação Escolar Iguassu em substituição a Associação Escolar 25 de Julho. Em ata de 9 de setembro de 1938 registra-se a correspondência recebida em 29 de agosto de 1938 do Inspetor Geral das Escolas Particulares e Nacionalização do Ensino, Luiz Sanches Bezerra da Trindade, dirigida ao diretor da escola alemã (COLLÉGIO IGUASSÚ, 1938-1941):

\begin{abstract}
Em referência ao seu requerimento de 3 do corrente [agosto de 1938], comunicoIhe que a denominação da Escola Iguassu em substituição ao antigo nome, devese enquadrar nos dispositivos da lei, isto é, deve ser feita a modificação correspondente com o respectivo despacho nos estatutos da sociedade escolar responsável por esse estabelecimento. A prova desse registro deve ser enviada a esta Inspetoria Geral. (COLLÉGIO IGUASSÚ, 1938-1941, p. 3, verso).
\end{abstract}

Percebe-se nessa devolutiva que também a escola sofreu alteração de nominação passando a Escola Iguassu, o que não ficou evidente na ata anterior. Porém, o documento despachado, e transcrito na ata de 9 de setembro de 1938, assim se refere: "ao Snr. Friedhold Altmann, Diretor da Escola Iguassu - Porto União. O Snr. Diretor foi então incumbido de providenciar imediatamente a regularização dos documentos ainda solicitados no offício supra”. (COLLÉGIO IGUASSÚ, 1938-1941, p. 3 verso).

Em primeiro de fevereiro de 1939 consta o registro da alteração do nome do presidente eleito em junho de 1938, ficando em seu lugar o secretário. Percebe-se que a anterior sugestão do Inspetor, ainda não tinha sido oficializada, o que deveria ter ocorrido em agosto de 1938. Outra reunião aconteceu em primeiro de março de 1939. Nesta foram tratados os assuntos sobre a prestação de contas, a contratação de funcionários ${ }^{11}$.

Na reunião do dia 25 de março de 1939 ocorreu a leitura do oficio (15 de março), dirigido ao diretor Friedhold Altmann, pelo secretário da pasta do Interior, Justiça, Educação e Saúde ${ }^{12}$, com o seguinte teor (COLLÉGIO IGUASSÚ, 1938-1941):

\footnotetext{
${ }^{11}$ Foi contratada uma nova zeladora para o internato, a Dna. Ema Reütuers. Em substituição ao professor Reinhold Fuck, que desistiu do cargo, foi contratada a professora Lydia Senff; em substituição a professora de Educação Física que fora exonerada, assumiu o professor Friedhold Altmann. Em 1939 havia 50 alunos matriculados e mais 16 alunos no Jardim de Infância. (COLLÉGIO IGUASSÚ, 1938-1941).

12 Ivo D'Aquino Fonseca, durante o governo de Nereu Ramos (1937 a 1945) foi escolhido para integrar o secretariado do Governador eleito, ocupando a pasta do Interior, Justiça, Educação e Saúde. Como
} 
Snr. professor: à vista dos motivos expostos no parecer do Sr. Inspetor Geral das Escolas Particulares e Nacionalização do Ensino e por estar funcionando clandestinamente no estabelecimento um Jardim de Infância, determino o fechamento dos cursos primários e pré-primário do Colégio Iguassú de Porto União, até serem sanadas as irregularidades apresentadas naquele parecer que contravêm ao Decreto $n^{\circ}$ 18, de 31-3-38. Florianópolis, 15-3-39. Ass. Ivo D’Aquino. (COLLÉGIO IGUASSÚ, 1938-1941, p. 9 verso).

Esclarecendo o documento, o Inspetor assim se manifesta (COLLÉGIO IGUASSÚ, 1938-1941):

Junto também cópia do parecer que dei no referido processo. Assim sendo, deveis providenciar o fechamento do referido Estabelecimento, afim de que seja solicitada nova licença, organizando a sociedade, de forma a não deixar, dúvida sobre o seu espírito de brasilidade, si o desejar, um novo processo, na forma da legislação em vigor. Os alunos da Escola Iguassú devem ser encaminhados a outros estabelecimentos de ensino para não serem prejudicados. Saúde e Fraternidade. (Ass.) Luiz Sanches Bezerra da Trindade. Inspetor Geral das Escolas Particulares e Nacionalização do Ensino. (COLLÉGIO IGUASSÚ, 1938-1941, p. 10).

O parecer, que desencadeou o fechamento da escola, redigido por Luiz Sanches Bezerra da Trindade à Secretaria do Interior e Justiça do Estado, também foi anexado à documentação enviada ao Colégio Iguassú, e assim foi transcrito (COLLÉGIO IGUASSÚ, 1938-1941):

Parecer $n^{\circ}$ 10. Snr. Superintendente. Estudando o processo, estou convencido da má fé da direção da Escola, em cumprir os dispositivos legais, em relação aos serviços de nacionalização do ensino. Sinão vejamos: 1 - O requerimento inicial é de 14 de junho de 1938 e deu entrada na Secretaria do Interior em 18 do mesmo mês e ano, e nele há a declaração (parag. 3) "Os cursos que manterão são o primário e o complementar". Em 18 de fevereiro deste ano, a direção da Escola comunica que as aulas foram reabertas com a matrícula total de 60 alunos, "sendo 12 do Jardim de Infância, 36 do curso primário e 12 do curso complementar. 2- Em primeiro de julho de 1938 esta Inspetoria reclamou documentos e selos que faltavam no processo os quais foram remetidos em 8-7-38. 3- Em 11 de julho de 1938, dei parecer esclarecendo falhas e irregularidades no processo e o Exmo. Snr. Dr. Secretário do Interior e Justiça determinou: Friedhold Altmann, requereu licença para o funcionamento do Colégio mantido pela "Associação 25 de Julho" de Porto União. Apresenta entretanto, como responsável pelo estabelecimento o Snr. [?], residente em União da Vitória, Estado do Paraná. Não pode ser aceito por inconveniência aos interesses do ensino. Deve, assim, o requerente apresentar o nome de pessoas residentes na sede da escola, para responsável por ella, nos

responsável pela política educacional do estado, coube-lhe elaborar as leis da campanha de nacionalização do ensino. A campanha foi autorizada por cinco decretos assinados por Nereu Ramos entre janeiro de 1938 e fevereiro de 1939. (FUNDAÇÃO GETULIO VARGAS - CPDOC, 2021). 
termos do Decreto-Lei no 88 , de 31 de março de 1938 . Bem como mudar o nome do estabelecimento de acordo com o processo do Departamento de Educação, baseado no art. 10, parágrafo único daquele Decreto-Lei. É concedido o prazo de quinze dias para o cumprimento dessas determinações. Intime-se. Florianópolis 27-7-38. (Ass.) Ivo D'Aquino. Esta Inspetoria deu ciência do despacho em ofício nos 72 e 73, de 29-7-38, ao Inspector Escolar e ao Diretor da Escola. Em 3 de agosto de 1938 o sr. Professor Friedhold Altmann, diretor da escola declara: "que a escola passou a ser denominada Iguassú e que assumiu a presidência da sociedade o snr. [?] em substituição ao snr. [?]. À vista das relações desta inspetoria, em ofícios de 29-8-938 e 9-11-939, o snr. Diretor da Escola remeteu em 6-11-938 os Estatutos da sociedade modificados, os quais foram publicados no Jornal "Folha do Povo" de Porto União, em 30 de outubro de 1938. As firmas dos signatários foram reconhecidas em 7-11-938. Estes estatutos tem a assinatura do snr. [?], como presidente da Sociedade, e do snr. [?] como secretário. Assinalei as datas e as ressalto novamente para provar a má fé nas afirmações feitas: A- 3 de agosto de 1938 - Comunicação de ter assumido a presidência o snr [?] [antigo secretário da diretoria anterior]. B- 14 de outubro de 1938, reformados os estatutos, presidente snr. [?] [não foi substituído o nome do presidente]. Ainda mais: Fiz sentir ao Diretor da Escola a irregularidade apontada, em ofício $n^{\circ} 116$, de 24 de janeiro $\mathrm{p}$. passado. Resultou dessa reclamação a remessa da ata da sessão extraordinária realizada em $1^{\circ}$ de fevereiro de 1939 (convém anotarmos bem esta data) na qual se elegeu o snr. [?] - presidente da sociedade. Conclusão: o snr. [?] só foi eleito presidente da Associação Escolar Iguassú, de Porto União em $1^{\circ}$ de fevereiro de 1939, e não nas datas anteriormente comunicadas em ofícios. Além disso, está funcionando clandestinamente o Jardim de Infância em transgressão aos dispositivos legais em vigor. Penso, s.m.j que está bem clara a má fé dos dirigentes da sociedade e, assim sendo, opino pelo fechamento definitivo da Escola, como prejudicial à nacionalização. Fpólis, 1-3-939. (Ass.) Luiz Sanches Bezerra da Trindade. Inspetor Geral das Escolas Particulares e Nacionalização do Ensino. (COLLÉGIO IGUASSÚ, 1938-1941, p.10-11).

Mediante o referido parecer as aulas encerraram-se até segunda ordem. O presidente da associação e o diretor da escola foram procurar o advogado da instituição a fim de tentar reverter a decisão de fechamento. Houveram várias tratativas, encaminhamento de requerimentos e telegramas. Entretanto, até o dia 12 de abril de 1939, não havia nenhum retorno e os membros da associação reuniram-se para deliberar algumas dispensas de professores, em virtude e o colégio ainda estar fechado e os membros da associação terem despesas a vencer ${ }^{13}$.

O professor Friedhold, surpreso com essa situação de irregularidade, comenta (ALTMANN, 1991):

Mas, o que seria isso? Estava tudo em ordem. O inspetor [inspetor local das escolas primárias] não sabia de irregularidades. A nossa diretoria contratou um advogado, que foi a Florianópolis para saber o que havia. Voltou com a notícia de

${ }^{13}$ Foram dispensados os professores: Zenaide de Araújo, Lydia Senff, Nair Godoy Eggers e Therese Roschitz. O Diretor ficaria até o dia 30 de abril. (COLLÉGIO IGUASSÚ, 1938-1941, p. 12 verso). 
que na escola estava funcionando um jardim de infância clandestino. Ora, quando eu tinha vindo a Porto União, cinco anos antes, o jardim já estava funcionando. Mensalmente tinha sido remetido um relatório sobre as atividades. $O$ inspetor [local] sempre tinha visto e visitado o jardim durante anos. Agora, o jardim estava aí clandestinamente? Ajuntamos documentações e provas de defesa. O advogado levou esse documento a Florianópolis. O processo foi registrado. Seria estudado. Ficamos aguardando, pois. Os dias se passavam uns após os outros. As aulas deveriam ter sido iniciadas. Os pais dos alunos apareciam preocupados. As nossas consultas sempre tinham as mesmas respostas: "O processo ainda não foi julgado". A diretoria via, e nós também, que os nossos alunos, um após o outro, procuravam matrícula em outras escolas. Os professores foram despedidos, pois quem os haveria de pagar? Eu fui mantido como diretor. A escola estava fechada ainda no mês de abril. Então a diretoria me comunicou que, em virtude de força maior, não havia mais condições de manter o meu contrato de emprego [...]. O que fazer agora? Lá estava eu com a mulher, proibida de trabalhar por ter nascido na Alemanha. Eu, sem emprego. Minha escola fechada até "sanar irregularidades" [...]. Ricarda [esposa] estava grávida. Os nossos recursos em dinheiro eram poucos. Já naquele tempo era assim: de um professor exigia-se o idealismo; dinheiro não era importante [...]. (ALTMANN, 1991, p. 82).

Depois de fechada a escola, restaram alguns encaminhamentos como deliberações sobre o uso do prédio que segundo Altmannn (1991) foi ocupado pelo Fórum da cidade, depois Prefeitura, Corpo de Bombeiros, Casa da Cultura e atualmente Secretaria Municipal de Educação. O diretor Friedhold Altmann e a esposa transferiram-se para uma escola na cidade de Marcelino Ramos, no Rio Grande do Sul. Em 1940 houve uma eleição da diretoria da Associação e os membros seriam reconduzidos em seus cargos até 21 de julho de 1941. Em 17 de janeiro de 1941 a Associação Escolar Iguassú optou por realizar uma fusão com a Sociedade Beneficente e Recreativa União da Vitória tendo em vista algumas dívidas a serem quitadas e uma hipoteca. A sociedade que sucederia tinha interesse em quitar a dívida. Com a extinção da Associação Escolar Iguassú, os membros passaram a fazer parte, como sócios, da Sociedade Beneficente e Recreativa União da Vitória. Em 28 de janeiro de 1941 foi oficialmente extinta a Associação Escolar Iguassú e incorporado o patrimônio da primeira à última, e a diretoria foi dissolvida (COLLÉGIO IGUASSÚ, 1938-1941).

\section{APONTAMENTOS}

O Período Republicano brasileiro foi permeado por um contexto de intensas mudanças. Uma delas refere-se à aproximação com um novo modelo de sociedade afirmando-se na industrialização, no comércio e em atividades artísticas e culturais. Paralelamente a isso houve uma forte influência da corrente positivista que apontava o 
predomínio da ciência e do método empírico sobre o pensamento religioso. Essa corrente filosófica influenciou a elaboração da Constituição Republicana, estabelecendo um Estado laico separando Estado e religião. Além disso, por preconizar o predomínio da ciência provocou alterações no setor educacional, modificando o currículo escolar, procurando torná-lo mais científico. A República brasileira trouxe, ainda a determinação de instaurar um nacionalismo, o qual surgiu fortemente entrelaçado com as ideias positivistas, ou seja, tinha por função manter a ordem e garantir um progresso à luz das ciências. Ocorreram campanhas em prol da formação de uma nação típica brasileira que tivesse uma identidade nacional voltada para uma língua pátria, um sentido de cidadania, uma cultura com valores próprios, uma história do Brasil, uma geografia própria, etc.

No ano de 1937, no período denominado de Estado Novo, do governo Getúlio Vargas, intensificou-se o ideário nacionalista. Coube a escola formar o cidadão brasileiro e incutir-lhe o sentimento de pertencimento à Pátria. A escola deveria conduzir os estudantes a uma formação cívico patriótica, ensinar os símbolos nacionais, oportunizar desfiles escolares, formar os escoteiros, realizar sessões cívicas no interior da escola com hasteamento da bandeira, declamações de poesias em homenagens aos heróis nacionais, utilizar de medidas higienistas como forma de aprimorar as raças, deveria ensinar em língua nacional, entre outras medidas.

A determinação de que as escolas deveriam ensinar em língua nacional refletiu sobre a prática pedagógica no interior das escolas étnicas estabelecidas principalmente no sul do país e em áreas rurais de colonização de imigrantes europeus que fixaram-se desde o final do século XIX. Havia locais em que a população ainda não dominava a língua portuguesa e as crianças chegavam à escola sem saber falar em português. Segundo Santos (2014):

[...] o advento da nacionalização imprimiu marcas profundas no funcionamento das escolas das zonas coloniais. Ao se considerar as perspectivas da legislação exarada, tanto no âmbito estadual como federal, naquele período e que foi orientada pelo ideário nacionalista, os seus impactos na administração, na docência, nos currículos e nas relações entre as escolas e as comunidades do entorno - tudo isto determinou tal mudança histórica. (SANTOS, 2014, p. 241). 
No ano de 1938 foi publicado o Decreto Federal $n^{\circ}$ 406, de 04 de maio, conhecido como Lei da Nacionalização que determinava em seus Artigos de 85 a 87 (BRASIL, 2021):

\begin{abstract}
Art. 85. Em todas as escolas rurais do país, o ensino de qualquer matéria será ministrada em português, sem prejuízo do eventual emprego do método direto no ensino das línguas vivas. $\S^{\circ}$ As escolas a que se refere este artigo serão sempre regidas por brasileiros natos. $\S 2^{\circ}$ Nelas não se ensinará idioma estrangeiro a menores de quatorze (14) anos. $\S 3^{\circ}$ Os livros destinados ao ensino primário serão exclusivamente escritos em línguas portuguesa. $\S 4^{\circ}$ Nos programas do curso primário e secundário é obrigatório o ensino da história e da geografia do Brasil. $\S 5^{\circ}$ Nas escolas para estrangeiros adultos serão ensinadas noções sobre as instituições políticas do país. Art. 86. Nas zonas rurais do país não será permitida a publicação de livros, revistas ou jornais em línguas estrangeira, sem permissão do Conselho de Imigração e Colonização. Art. 87. A publicação de quaisquer livros, folhetos, revistas, jornais e boletins em língua estrangeira fica sujeita à autorização e registro prévio no Ministério da Justiça. (BRASIL, 2021).
\end{abstract}

Os estados do sul do Brasil anterior ao decreto de 1938 já haviam passado por reformas educacionais com tendências nacionalizadoras, porém mais brandas que exigiam algumas adequações acessíveis. Entretanto, as determinações do referido decreto direcionaram para o fechamento definitivo de muitas escolas étnicas e fixaram um marco na história do ensino primário no sul do Brasil. Fato que também resultou no fechamento da escola alemã de Porto União (SC).

O referido decreto apresentava muitas restrições quanto a entrada e permanência de imigrantes no país. Situação que no final do século XIX foi amplamente incentivada. Esse controle afetou diretamente os imigrantes alemães que entravam no país e indiretamente os que já estavam estabelecidos. As restrições foram consequências da preocupação com os fatos que estavam ocorrendo na Europa e principalmente na Alemanha. Este estado de alerta inquietava os imigrantes alemães fixados no Brasil. Constata-se essa inquietação nas palavras do pastor, vindo de Neuendettelsau (Alemanha), na década de 1930, quando observava a construção do novo colégio: "qual será o futuro dessa casa que se constrói com tanto entusiasmo e também sacrifício?" (ALTMANN, 1991). E, o professor Friedhold Altmann no auge de sua juventude, tirava suas conclusões (ALTMANN, 1991):

Tudo estava tão bem. A nossa escola seria uma escola para crianças para sempre. Mas, vindo da Alemanha, sabia da ascensão da nova Alemanha com o governo do Führer e sentia também que nuvens escuras cada vez mais se fechavam sobre o 
céu político da Europa e com isto sobre todo o mundo. Deve ter percebido a ameaça que isso representava para a Alemanha para o povo alemão e como facilmente poderia estender os seus efeitos para o Brasil, atingindo com suas ondas também alemães aqui, inclusive Porto União e a nossa escola [...]. (ALTMANN, 1991, p. 71).

Esses encaminhamentos na Europa fizeram com que houvesse um temor, por parte das autoridades brasileiras, de que os imigrantes se fortalecessem e provocassem conflitos internos. Por isso, as sociedades dos imigrantes foram monitoradas, as escolas que ensinavam em alemão sofriam fiscalização, os materiais escritos em língua alemã foram proibidos, os cultos religiosos e as aulas em escolas étnicas deveriam acontecer somente em língua nacional.

Quanto a essa situação os professores da escola alemã, devido à sua nacionalidade, enfrentavam alguns preconceitos (ALTMANN, 1991):

Em Porto União tinham aparecido os primeiros rádios de onda curta, através dos quais recebia-se transmissões da Europa. Ao voltar da refeição que fazíamos no hotel, sempre chegávamos a um bar onde podíamos ouvir o noticioso da Alemanha. Certa noite, houveram hóspedes que reclamaram. Não queriam que ouvíssemos transmissões da rádio alemã. O pretexto era de que queriam ouvir a transmissão de um jogo de futebol. O dono do bar, alemão, porém respondeu, que o rádio era dele e que ele também estava interessado nas notícias da Alemanha. Logo depois poderiam ouvir o jogo. Este foi apenas um acontecimento banal e pequeno, mas era um sinal. (ALTMANN, 1991, p. 77).

Situações de hostilidade também ocorreram com a professora do Jardim de Infância (ALTMANNN, 1991):

Nossa professora jardineira, que morava junto a uma família em União da Vitória, apareceu certa manhã queixando-se que tinha sido importunada e até cuspida por um grupo de rapazes, quando, como de costume, se dirigia à escola. Eu recomendei que mudasse seguidamente de trajeto. Isso amenizou, mas não resolveu o problema. (ALTMANN, 1991, p. 77).

As intolerâncias continuavam. Durante uma Semana Pedagógica promovida pela Secretaria de Florianópolis, em Porto União (SC), os professores da escola alemã participaram juntamente com outros educadores do município, e o professor Friedhold relatou (ALTMANN, 1991): 
programada uma noite de artes [...]. Foi sugerido que eu fizesse uma apresentação de músicas e canções gauchescas com minha gaita de botões. [...] todas as escolas públicas apresentaram seus números. [...] colhi fortes aplausos por parte da assistência, mas da mesa das autoridades vinham olhares amargos. Outro sinal. (ALTMANN, 1991, p. 78).

Referindo-se a esta semana pedagógica o professor Friedhold relembra a afirmação do Diretor do Departamento do Ensino Particular, nesta ocasião, que expressou o seguinte pensamento (ALTMANN, 1991):

\begin{abstract}
Sabemos que escolas particulares como as de Blumenau, Joinville, Brusque e outras, tem um nível de ensino mais elevado e corpo docente mais qualificado do que as nossas escolas. Sabemos que sua clientela e população tem um nível cultural diferente, mas é justamente isto que vamos mudar. Queremos que desçam ao nosso nível e, ombro a ombro, juntos, vamos constituir um Brasil maior, grande, forte e verdadeiramente brasileiro. (ALTMANN, 1991, p. 80).
\end{abstract}

A suposição de que as escolas particulares estrangeiras possuíam um currículo mais elevado culmina numa situação de concentração do saber em posse dos estrangeiros, o que provoca um cenário de perigo. E os constrangimentos se prolongavam até mesmo com situações inoportunas do ambiente externo para com o interior da escola (ALTMANN, 1991):

\footnotetext{
Certo dia apareceu uma professora queixando-se que tinha sido perturbada na sua aula, com o ensaio da banda da Brigada, logo abaixo da janela da sua classe. Era uma rua transversal apenas para pedestres. [...] talvez teria sido um caso isolado, mas não era. Os ensaios continuados nesse local e com grande conjunto de tambores, tornavam o trabalho em classe praticamente impossível. O nosso Diretor foi falar ao Comandante, pedir que procurassem outro local ou mudassem o horário para a tarde. A resposta foi de que estavam tocando na rua livre para todos. [...] como a situação tinha repentinamente mudado, desde o tempo em que essa mesma banda tocava as músicas alegres das danças para nossas crianças do jardim de infância. (ALTMANN, 1991, p. 78).
}

Com a intensificação da fiscalização sugeriu-se a substituição de professores alemães por brasileiros ou naturalizados. Ocorreu a exoneração do Diretor que antecedeu o professor Friedhold Altmann, o qual transferiu-se para a cidade de Niterói, no Rio de Janeiro, outro professor foi trabalhar numa empresa comercial, não mais continuando a carreira do magistério, outros ficaram sem trabalho. O nome da associação mantenedora teve que ser nacionalizado, ou seja, os membros deveriam escolher uma nomenclatura que não tivesse nenhuma ligação com a etnia alemã, os estatutos tinham que ser modificados 
e redigidos em português, e o fato das sociedades adquirirem bens incomodava as autoridades locais, pois havia uma concentração do poder econômico em mãos estrangeiras. A escola também teve que adaptar-se a uma nova nomenclatura: de Deutsche Schule passou a Colégio Teuto-Brasileiro e depois Collégio Iguassu. Os materiais didáticos escritos em alemão tiveram que ser suprimidos. As atas e toda a documentação deveriam ser escritas em língua portuguesa. Altmann (1991) descreve alguns transtornos com essas mudanças:

A mudança exigida tinha efeitos sensíveis e grandemente negativos sobre o nível de ensino da escola. [...] a exclusão total da língua alemã dificultava o trabalho, pois havia crianças que vinham à escola ou ao jardim, sem saber falar o português. $\mathrm{E}$, a escola devidamente nacionalizada, funcionava agora com o nome de Colégio Iguaçú. (ALTMANN, 1991, p. 79).

O professor Friedhold (ALTMANN, 1991, p. 93) descreve as consequências dessas medidas nacionalizadoras lembrando que muitos jornais editados em língua alemã deixaram de existir, alega um empobrecimento cultural onde as pessoas não liam mais e isso gerava um verdadeiro analfabetismo, "pais que não sabiam português não podiam ler as coisas que seus filhos mandavam dos quarteis, onde prestavam serviço militar. Estes por sua vez, não sabiam ler as cartas de seus pais". Destaca que nos cultos dominicais muitos adultos não entendiam o que o pastor pregava e não entendiam o que estavam rezando. O professor chama atenção para o fato de que juntamente à decadência cultural percebiase imediatamente uma decadência econômica, moral e ética. Segundo esse professor, tradição, costumes, língua e a história de uma pessoa fazem parte do seu ser e se tornam inseparáveis de sua personalidade.

\section{CONSIDERAÇÕES FINAIS}

A história da escola alemã de Porto União (SC), estudada no breve período de 1938 a 1941, resume toda a caminhada da organização do ensino, efetivada pelos alemães luteranos dessa localidade. Esse grupo étnico já instalado no município a mais de meio século, previu para seus descendentes uma escola atrelada aos princípios religiosos e ao mesmo tempo organizada pela comunidade, demonstrando a determinação, disciplina e a significativa relevância que a escolarização tinha para as gerações subsequentes. Esses 
alemães, com o seu trabalho, contribuíram com o progresso local, introduziram a cultura, os costumes, a língua e outras tradições. E, quanto a escola, queriam o melhor para as crianças. Desejavam uma escola com um currículo supostamente <forte>, com o ensino do alemão, através do ditado, da leitura, da composição, da gramática, ofertavam a história natural, o canto, a ginástica entre outros. Providenciavam os materiais didáticos, selecionavam os melhores professores, realizavam os pagamentos dos educadores por meio de uma sociedade mantenedora. Além disso, havia um internato para que estudantes de localidades mais distantes também tivessem a oportunidade de estudar, num tempo histórico em que a distância, a comunicação, o transporte e o próprio ensino consistiam em privilégios para poucos.

Entretanto, alguns fatos nacionais e internacionais alteraram o curso desse projeto. As políticas adotadas pelo governo alemão trouxeram como consequência um recrudescimento na tratativa dos grupos étnicos estabelecidos no Brasil. O modelo republicano adotado no país, previu um ensino laico e a organização da escola pública. Houve a intenção de implantar uma escola primária unificada, criou-se o Ministério da Educação e a intenção de estabelecer um Sistema Nacional de Educação. Diante desse novo quadro, as associações educativas perdiam a função e desmantelava-se a proposição de manter a cultura, conservar a língua do país de origem, as tradições, os materiais impressos e até mesmo a religiosidade, pois o ensino laico proporcionava o distanciamento das raízes religiosas.

Quanto ao trabalho dos inspetores escolares, estes atendiam aos interesses do Estado, principalmente no que se referia à efetivação de reformas educacionais. Tinham a função de fiscalizar as práticas pedagógicas e educativas e verificar a documentação da instituição. No período da República foram indispensáveis para colocar em prática, sobretudo os ideais nacionalistas e concretizar as propostas educacionais fundamentadas pelo Decreto Federal $n^{\circ}$ 406, de 04 de maio de 1938, conhecido como Lei da Nacionalização, levando ao encerramento das atividades das escolas étnicas ainda existentes no país.

A imposição da lei não afetou somente as ações físicas de uma instituição a qual teve que demitir professores, transferir patrimônio e dissolver a associação, mas interrompeu projetos de vida. Fez com que pessoas mudassem de cidade, professores assumissem outras profissões, levou as comunidades religiosas a adaptarem os cultos à 
Revista do Programa de Pós-Graduação em Educação da Unochapecó ISSN 1984-1566 (on-line) ISSN 1415-8175 (impressa)

língua pátria, conduziu pessoas ao auto isolamento por receio de não dominarem o idioma brasileiro, e incutiu traumas pelo preconceito étnico existente naquele momento.

Quando Ihlenfeld (2011) redigiu a primeira parte da história da escola alemã, na última linha de seu trabalho escreveu que sugeria a continuidade da pesquisa. O livro de atas que gerou esse trabalho só ficou conhecido mais tarde, e resultou nesse texto, coincidência ou não, mas o temor das consequências que os documentos da associação escolar pudessem provocar, pode ter sido o motivo que fez os registros desaparecerem por um longo período.

\section{REFERÊNCIAS}

ALTMANN, Friedhold. Memórias de um Professor. Lajeado; Rio Grande do Sul: Sinodal, 1991.

BARBOSA, Luciane Muniz Ribeiro. As Concepções Educacionais de Martinho Lutero. Educação e Pesquisa. v.33, n.1, p. 163-183, jan./abr. 2007. Disponível em: https://www.scielo.br/j/ep/a/tBR8R4H5zwGVm3fhZqyTnqg/?lang=pt\&format=pdf. Acesso em: 05 jun. 2021.

BRASIL. Decreto-Lei n 406, de 4 de maio de 1938. Dispõe sobre a entrada de estrangeiros no território nacional. Disponível em:

https://www2.camara.leg.br/legin/fed/declei/1930-1939/decreto-lei-406-4-maio-1938348724-publicacaooriginal-1-pe.html. Acesso em: 12 abr. 2021.

COLLÉGIO IGUASSÚ. Livro de Atas da Associação 25 de Julho. Porto União; Santa Catarina: 21 de jun. 1938 a 28 de jan. 1941. (1938 - 1941). (Documento não publicado).

FIORI, Neide Almeida. Aspectos da evolução do ensino público: ensino público e política de assimilação cultural no Estado de Santa Catarina - períodos Imperial e Republicano. 2. ed. Florianópolis; Santa Catarina: UFSC, 1991.176 p.

FUNDAÇÃO GETÚLIO VARGAS (FGV) - Centro de Pesquisa e Documentação de História Contemporânea do Brasil (CPDOC). Verbete. Ivo D'Aquino Fonseca. Biografia. Disponível em: http://www.fgv.br/cpdoc/acervo/dicionarios/verbete-biografico/ivo-d-aquino-fonseca. Acesso em: 23 abr. 2021.

GOHL, Marlei Kochman. A Missão Franciscana - contribuição de Frei João na educação brasileira (1956-2002). Curitiba; Paraná: Appris, 2017. 
Revista do Programa de Pós-Graduação em Educação da Unochapecó

ISSN 1984-1566 (on-line) ISSN 1415-8175 (impressa)

INSTITUTO BRASILEIRO GEOGRÁFICO - IBGE. Censo Demográfico 2010. Disponível em: https://cens02010.ibge.gov.br/sinopse/index.php?dados=0\&uf=41. Acesso em: 16 abr. 2021.

IHLENFELD, Carlos Egon. (Fotógrafo). [193?]. Escola Alemã de Porto União (SC). (Fotografia).

IHLENFELD, Renate. A presença da cultura alemã no pensamento pedagógico do Colégio Teuto Brasileiro de Porto União (SC) e sua influência sobre o imaginário dos alunos (1930-1938). 2011. 94 f. Monografia. Centro Universitário de União da Vitória (UNIUV), União da Vitória; Paraná, 2011.

KLUG, João. A Escola Alemã em Santa Catarina. In: DALLABRIDA, Norberto (Org.). Mosaico de Escolas. Florianópolis: Cidade Futura, 2003. p. 141-154.

KREUTZ, Lúcio. Escolas comunitárias de imigrantes no Brasil: instâncias de coordenação e estruturas de apoio. Revista Brasileira de Educação, n. 15, p. 159-176, set./dez. 2000.

Disponível em: https://www.scielo.br/scielo.php?pid=S1413-

24782000000300010\&script=sci_abstract\&tlng=pt. Acesso em: 12 abr. 2021.

MELO JUNIOR, Cordovan Frederico de. História do Colégio São José. Porto União; Santa Catarina: Uniporto, 1993.

PARÓQUIA PORTO UNIÃO. Livro Tombo I. Porto União; Santa Catarina, 1909 - 1941. (Documento não publicado).

RENK, Valquiria Elita. Aprendi falar português na escola: o processo de nacionalização das escolas étnicas polonesas e ucranianas no Paraná. 2009. 243f. TESE. UFPR, Curitiba; Paraná: 2009. Disponível em: https://acervodigital.ufpr.br/handle/1884/22024. Acesso em: 11 abr. 2021.

RENK, Valquiria Elita. Nacionalização Compulsória das Escolas Étnicas e Resistências, no Governo Varga. In: Congresso Nacional de Educação, 15, 2008, Curitiba. Anais... Curitiba: PUC -PR, 2008. p. 4285-4296. Disponível em:

https://educere.bruc.com.br/arquivo/pdf2008/620_436.pdf. Acesso em: 06 jun. 2021.

SANTOS, Ademir Valdir dos. As Escolas Alemãs em Santa Catarina e sua transformação para teuto-brasileiras: uma análise histórica. Revista Acta Scientiarum Educação, n. 2. p. 233-242, jul./dez. 2014. Disponível em:

https://periodicos.uem.br/ojs/index.php/ActaSciEduc/article/view/22232. Acesso em: 14 abr. 2021.

SILVA, Cleto da. Apontamentos Históricos de União da Vitória (1768-1933). 2. ed. Curitiba; Paraná: Imprensa Oficial do Paraná, 2006. 
Revista do Programa de Pós-Graduação em Educação da Unochapecó ISSN 1984-1566 (on-line) ISSN 1415-8175 (impressa)

UNGLAB, Tânia Regina da Rocha. Cultura escolar e práticas educativas embaladas por sons orfeônicos - uma história da educação catarinense. In: Simpósio Nacional de História, 28, 2015, Florianópolis. Anais.... Florianópolis: UDESC, 2015. p. 1 -11. Disponível em: http://snh2015.anpuh.org/resources/anais/39/1428364917_ARQUIVO_TExtoAnpuh.pdf.

Acesso em: 27 abr. 2021.

WACHOWICZ, Ruy. História do Paraná. 9. ed. Curitiba; Paraná: Imprensa Oficial do Paraná, 2001.

WEIDUSCHADT, Patrícia; TAMBARA, Elomar. O Sínodo de Missouri e o Seminário Teológico-Pedagógico em São Lourenço do Sul - RS (1903-1905). Revista HISTEDBR Online. Campinas, n. 48. p. 199-224. Dez. 2012. Disponível em: https://periodicos.sbu.unicamp.br > ojs > article > view. Acesso em: 06 jun. 2021.

WEIDUSCHADT, Patrícia. A revista "O Pequeno Luterano" e a formação educativa religiosa luterana no contexto pomerano em Pelotas - RS (1931-1966). TESE. São Leopoldo; Rio Grande do Sul: Unisinos, 2012. 275p. Disponível em: http://www.repositorio.jesuita.org.br/handle/UNISINOS/3615. Acesso em: 05 de jun. 2021.

Recebido em: 29 - 04 - 2021

Aprovado em: $25-06-2021$

Publicado em: $29-06-2021$ 